\title{
An exogenous cytokinin supply in the ornamental fern Asplenium nidus L. induces an unusual post-transplant biomass accumulation
}

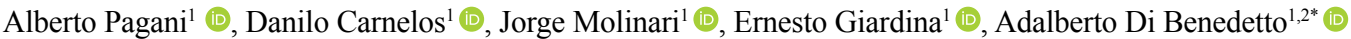 \\ ${ }^{1}$ Universidad de Buenos Aires, Buenos Aires-BA, Argentina. \\ ${ }^{2}$ Universidad Nacional de Mar del Plata, Provincia de Buenos Aires, Argentina
}

\begin{abstract}
Ferns are ornamental plants with a low relative growth rate and long production cycles, which are grown at small pot volumes to optimize the commercial space for sale. However, the root restriction effects under this plant management can limit biomass accumulation and frond area. Since an exogenous spray with cytokinin (6-benzyl aminopurine (BAP)) has been suggested as a tool to override the root restriction in plants grown in pots, this study aimed to evaluate the effect of different BAP doses $(5,50,100$ or $\left.200 \mathrm{mg} \mathrm{L}^{-1}\right)$ once ( 7 days after transplant), twice (7 and 30 days after transplant) or three times (7, 30, and 60 days after transplant), on plant growth and frond area development in spore-propagated Asplenium nidus fern plants grown in pots. Both increasing the BAP doses and number of applications led to an unusual response: an excessive decrease in the frond plastochron and a significant increase in the frond number initiated at the apical shoot meristem. This large frond number was not sustained due to the low net photosynthetic rate of the younger fronds and significantly limited outward appearance.
\end{abstract}

Keywords: growth regulator, leaf growth, ornamental foliage plants, pot root restriction.

\section{Resumo}

Suprimento de citocinina exógena em asplênio Asplenium nidus L. induzindo acúmulo não usual de biomassa após transplantio

Samambaias são plantas ornamentais com baixa taxa de crescimento relativo e longo ciclo de produção, sendo cultivadas em vasos de pequenos volumes para otimizar o espaço comercial para venda. No entanto, os efeitos da restrição de raízes sob o manejo da planta podem limitar o acúmulo de biomassa e a área das frondes. Um spray exógeno com citocinina (6-benzil aminopurina (BAP)) foi sugerido como ferramenta para substituir a restrição de raízes em plantas cultivadas em vasos. Este estudo teve como objetivo avaliar o efeito de diferentes doses de BAP $\left(5,50,100\right.$ ou $\left.200 \mathrm{mg} \mathrm{L}^{-1}\right)$ aplicadas uma vez (7 dias após o transplante), duas vezes (7 e 30 dias após o transplante) ou três vezes (7, 30 e 60 dias após o transplante), no crescimento da planta e no desenvolvimento da área da folhagem em Asplenium nidus cultivadas em vasos. O aumento das doses de BAP e do número de aplicações levou a uma resposta incomum: uma diminuição excessiva no plastocrono da fronde e aumento significativo no número de frondes iniciado no meristema apical do caule. Este grande número de frondes não foi sustentado devido à baixa taxa fotossintética líquida das frondes mais jovens e aparência externa significativamente limitada.

Palavras-chave: regulador de crescimento, crescimento foliar, plantas de folhagem ornamental, restrição de raízes em vasos.

\section{Introduction}

Ornamental plants with a low relative growth rate and long production cycles (24 months or more), such as ferns (Page, 2002; Liao et al., 2017), are grown in small pot volumes and frequently transplanted before sale. However, Asplenium nidus fern plants grown in small pots suffer from root restriction (Pagani et al., 2020), in agreement with previous reports in other ornamental potted plants (Di Benedetto et al., 2020a). In this regards, Pagani et al. (2020) showed that the use of large pots $\left(1500-\mathrm{cm}^{3}\right)$ in $A$. nidus increases fresh weight (FW), dry weight (DW) and frond area (the main commercial aesthetic trait). They also found higher frond appearance rate, frond area expansion, frond thickness, relative growth rate and net assimilation rate.

One of the main alternatives to override the root restriction syndrome in ornamental plants (Di Benedetto et al., 2020a) and vegetables (Di Benedetto et al., 2020b) is to use a synthetic cytokinin such as 6-benzyl aminopurine (BAP), which is able to regulate plant metabolism under abiotic stresses. The main effects of exogenous cytokinin on fern growth in culture have been described in detail (Kosakivska

*Corresponding author: dibenede@agro.uba.ar 
et al., 2016). In particular, Menendez et al. (2010) found that BAP induces bud formation and sporophyte production in $A$. nidus plants. Park et al. (2020) found that kinetin and BAP induce new shoots from the apical shoot meristem (SAM), while inhibiting rhizophore formation. In agreement, Souheil and Rola (2014) found that $A$. nidus plants grown in a solid medium supplemented with BAP and kinetin showed increased numbers of shoots and leaves and increased stem height. However, there are no reports on the effects of BAP during the commercial growth of $A$. nidus or other related spore-propagated ferns.

The fern A. nidus (Bird's nest fern), a common epiphytic ornamental, has a short, erect rhizome and a rosette of simple fronds. Leaf stalks are stout and almost black and can be as long as $5 \mathrm{~cm}$, whereas leaf length can be up to $150 \mathrm{~cm}$ or more and up to $20 \mathrm{~cm}$ wide. The plant narrows gradually, tapering both towards the pointed tip and towards the base. Although the life cycle of a fern includes two alternating generations: a diploid sporophyte and a haploid gametophyte, only the former has commercial significance. The fern A. nidus is native to tropical southeastern Asia and eastern Africa and it is in great demand as an ornamental plant.

Based on the hypothesis that an exogenous supply of BAP to the $A$. nidus sporophyte shoot would increase biomass accumulation by overriding root restriction, the aim of our work was to study the effect of different doses and one or more foliar sprays of BAP on plant growth and frond area development in $A$. nidus spore-propagated plants grown in pots.

\section{Materials and Methods}

Two experiments were carried out in a greenhouse located at the School of Agronomy, University of Buenos Aires, Argentina (3435'59'S, 58 $22^{\circ}$ '23' $\mathrm{W}$ and altitude $25 \mathrm{~m}$ ), in successive years, from October $10^{\text {th }} 2017$ to February $9^{\text {th }} 2018$, and from October $8^{\text {th }} 2018$ to February $11^{\text {th }} 2019$ (Experiments 1 and 2, respectively).

Plantlets from spores grown in 128-plug-cell trays ${ }^{-1}$ of A. nidus L. were obtained from a commercial propagator and then transplanted into rigid $1500-\mathrm{cm}^{3}$ plastic pots (one plant per pot). The pots were filled with a 40:40:20 (v/v/v) mix of Sphagnum maguellanicum peat:river waste: perlite.

Plants were irrigated as needed with high-quality tap water ( $\mathrm{pH}$ : 6.64 and electrical conductivity of $0.486 \mathrm{dS}$ $\mathrm{m}^{-1}$ ) using intermittent overhead mist, and one weekly fertigation $(1 \mathrm{~N}: 1 \mathrm{P}: 1 \mathrm{~K}: 1 \mathrm{Ca} v / \mathrm{v} / \mathrm{v} / \mathrm{v})\left(50 \mathrm{mg} \mathrm{L}^{-1} \mathrm{~N}\right)$ was included.

Half hourly averages of the air temperature were measured using a HOBO H08-001-02 data logger (Onset Computer Corporation, MA, USA) protected from direct radiation by aluminum foil shades. The mean air temperatures ranged between $22.7{ }^{\circ} \mathrm{C}$ and 26.08. The greenhouse was covered with a black shade cloth (for 50\% full sunlight) and mean photosynthetic active radiation during the experiment ranged between 7.10 and $10.60 \mathrm{~mol}$ photons $\mathrm{m}^{-2}$ day $^{-1}$. The plants were arranged at a density of 6 plants $\mathrm{m}^{-2}$ to avoid mutual shading.

In Experiment 1, plants were sprayed with 0 (distilled water control), 5, 50, 100 or $200 \mathrm{mg} \mathrm{L}^{-1} 6$, benzyl amino purine (BAP) solutions (Sigma-Aldrich Co., St. Louis, MO, USA) 7 days after transplanting. In Experiment 2, plants were subjected to different numbers of BAP applications, by spraying them with 0 (distilled water control), 5, 50, 100 or $200 \mathrm{mg} \mathrm{L}^{-1}$ BAP solutions at different times. Applications were performed once ( 7 days after transplant), twice ( 7 and 30 days after transplant) or three times $(7,30$, and 60 days after transplant). The BAP concentrations were chosen from the results of a preliminary experiment not included in this work. In both experiments, all leaves were sprayed to run-off at sunset (approximately $50 \mathrm{~mL} \mathrm{pot}^{-1}$ ). BAP was first diluted in $80 \%$ ethanol and no surfactants were added.

Plants for destructive measurements were harvested at transplant and at 30-day intervals in Experiment 1, and at transplant and at 30-day intervals after the last BAP spray in Experiment 2. Roots were washed, and root, stem and frond FWs were recorded. DWs were recorded after drying roots, stems and fronds to constant weight at $80^{\circ} \mathrm{C}$ for 96 hours. The number of fronds was recorded and each frond area was determined using the Image $\mathbb{~}{ }^{\circledR}$ (Image Processing and Analysis in Java) software.

The rate of leaf appearance (RLA), the relative growth rate (RGR), the rate of leaf area expansion (RLAE), the mean net assimilation rate (NAR), the leaf area ratio (LAR), the specific leaf area (SLA), the leaf area partitioning (LAP), the allometric coefficients $(\beta)$ between roots: shoots and fronds: stems were calculated as previously (Di Benedetto and Tognetti, 2016).

The experimental design was a randomized one with four BAP applications for Experiment 1 and four BAP concentrations and three times of BAP application for Experiment 2. Data were subjected to a one-way and twoway analysis of variance (ANOVA) using STATISTICA 8 software (StatSoft) after checking ANOVA assumptions for Experiments 1 and 2 respectively. Means were separated by Tukey's tests $(\mathrm{p} \leq 0.05)$. Slopes from straightline regressions of RLAE, RGR, NAR, LAR, LAP and allometric $\beta$ coefficients were tested using the SMATR package.

\section{Results and Discussion}

In Experiment 1 of the present study, a single BAP spray on $A$. nidus spore-propagated sporophytes led to significant changes in aesthetic traits such as a decrease in frond size and an increase in SAM (Figure 1). 

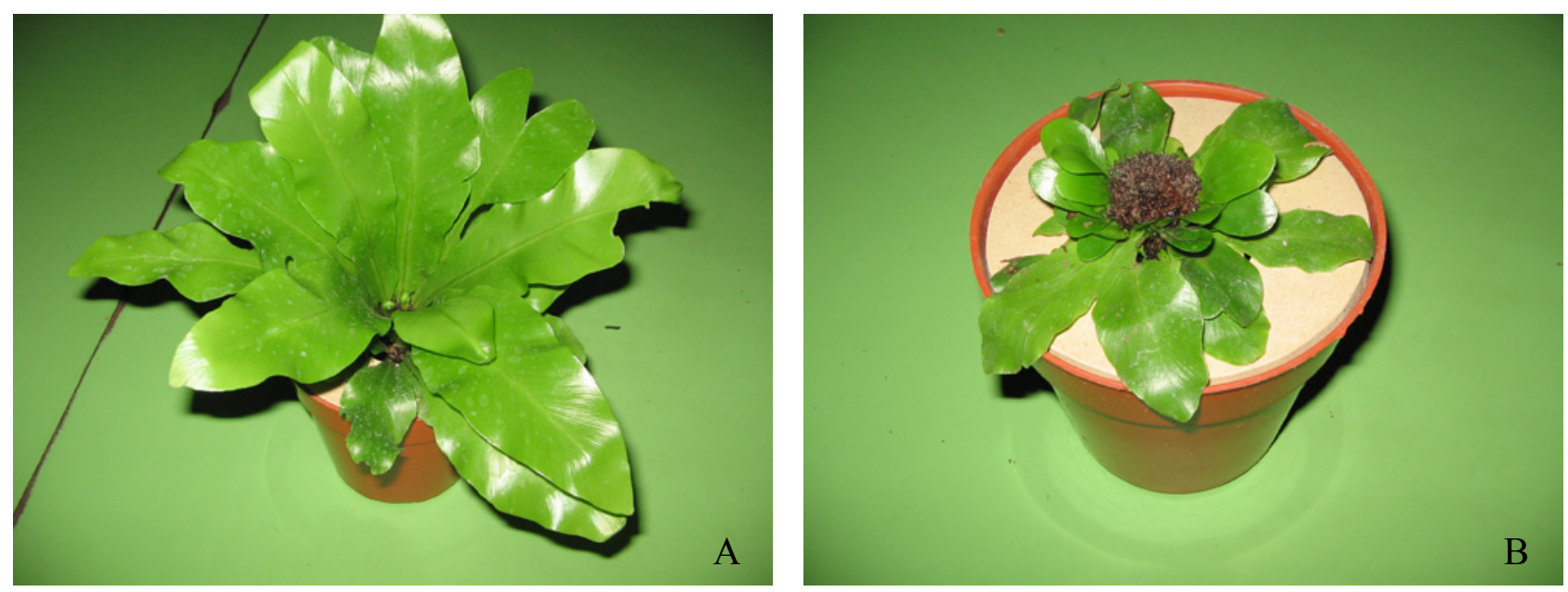

Figure 1. Control Asplenium nidus plants (A) and Asplenium nidus plants sprayed with a single $200 \mathrm{mg} \mathrm{L}^{-1} 6$-benzyl aminopurine (BAP) (B) at the end of Experiment 1 . Horizontal lines indicate the $1 \mathrm{~cm}$ scale.

When BAP dose increased, SAM differentiated a significantly higher number of lateral growth areas (290.91\% compared to controls) (Figure 2), while RLA increased (120.89\%), but RLAE $(100.20 \%)$ and SLA (70.60\%) decreased (Table 1).

In homogenate cultures from sporophytes of $A$. nidus, both gametophyte and sporophyte regeneration take place in a hormone-free medium (Fernández et al., 1993), which indicates that explants have enough endogenous hormones to start to grow. However, it has been shown that, during the micro-propagation of many ferns, sporophyte formation increases by adding BAP (Ravi et al., 2015). In addition, previous reports on sporophytes of $A$. nidus cultured in a medium supplemented with BAP have shown that rhizomes become swollen due to bud proliferation induced by the synthetic cytokinin (Fernández et al., 1993). However, few studies have evaluated the effects of exogenous cytokinin on spore-propagated sporophyte biomass accumulation.

At the end of Experiment 2, during which four BAP concentrations at three times of application were tested, total frond area decreased as both the BAP concentration and number of applications increased (Figure 3).

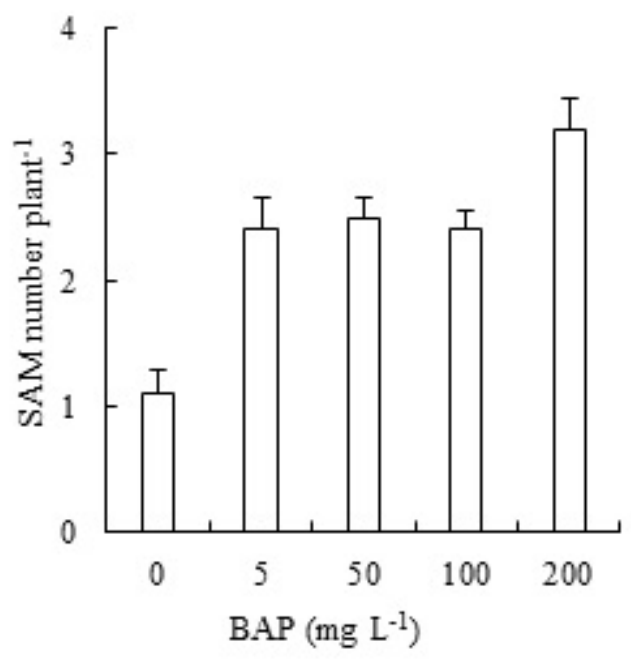

Figure 2. Effects of five 6-benzyl aminopurine (BAP) concentrations (0, 5, 50, 100 or $\left.200 \mathrm{mg} \mathrm{L}^{-1}\right)$ on the number of lateral vegetative meristems (SAM) at the end of Experiment 1 in Asplenium nidus plants. 
Table 1. Effects of five 6-benzyl aminopurine (BAP) concentrations (0, 5, 50, 100 or $\left.200 \mathrm{mg} \mathrm{L}^{-1}\right)$ on total and individual frond area and specific leaf area (SLA) on a fresh weight basis at the end of the experiment 1, rate of leaf appearance (RLA) and relative leaf expansion rate (RLAE) in Asplenium nidus plants. Different lower case letters indicate significant differences $(p<0.05)$ between treatments according the Tukey's Test (number of frond and frond area) or SMATR analysis (RLA, RLAE and SLA).

\begin{tabular}{|c|c|c|c|c|c|}
\hline $\begin{array}{c}\text { BAP } \\
\left(\mathrm{mg} \mathrm{L}^{-1}\right)\end{array}$ & $\begin{array}{c}\text { Number of fronds } \\
\text { plant }^{-1}\end{array}$ & $\begin{array}{l}\text { Frond area } \\
\left(\mathrm{cm}^{2} \text { frond }^{-1}\right)\end{array}$ & $\begin{array}{c}\text { RLA } \\
\text { (fronds week }{ }^{-1} \text { ) }\end{array}$ & $\begin{array}{c}\text { RLAE } \\
\left(\mathrm{cm}^{2} \mathbf{c m}^{-2} \text { day }^{-1}\right)\end{array}$ & $\begin{array}{c}\text { SLA } \\
\left(\mathrm{cm}^{2} \mathbf{g}^{-1}\right)\end{array}$ \\
\hline 0 & $44.25 \mathrm{~d}$ & $321.69 a$ & $1.958 \mathrm{e}$ & $0.0099 a$ & $65.99 a$ \\
\hline 5 & $59.60 \mathrm{~b}$ & $201.10 b$ & $2.811 \mathrm{~b}$ & $0.0075 b$ & $36.70 \mathrm{~b}$ \\
\hline 50 & $78.90 \mathrm{a}$ & $153.48 \mathrm{c}$ & $3.883 \mathrm{a}$ & $0.0075 b$ & $28.41 \mathrm{c}$ \\
\hline 100 & $57.00 \mathrm{~b}$ & $134.60 \mathrm{~d}$ & $2.667 \mathrm{c}$ & $0.0068 b$ & $21.59 \mathrm{~d}$ \\
\hline 200 & $51.60 \mathrm{c}$ & $62.80 \mathrm{e}$ & $2.367 d$ & $-0.0002 c$ & $19.04 d$ \\
\hline
\end{tabular}

\section{ㅁI $\square$ III}

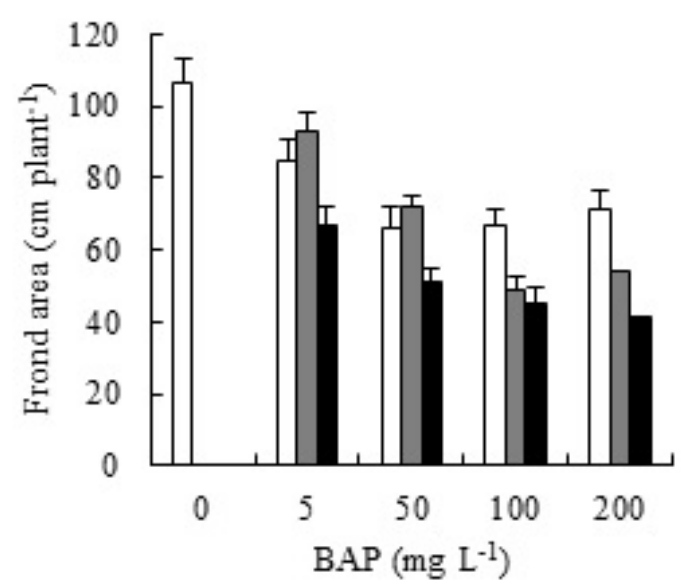

Figure 3. Effects of five 6-benzyl aminopurine (BAP) concentrations (0, 5, 50, 100 or $\left.200 \mathrm{mg} \mathrm{L}^{-1}\right)$ applied once ( 7 days after transplant) (I), twice (7 and 30 days after transplant) II or three times (7, 30, and 60 days after transplant) (III) on total frond area at the end of Experiment 2 in Asplenium nidus plants. Bars indicate standard errors.

Figure 4 shows an example for $5 \mathrm{mg} \mathrm{L}^{-1} \mathrm{BAP}$ repeatedly sprayed plants. The results from Experiment 2 showed that frond number and RLA significantly increased according to the BAP concentration and number of applications (Table 2), while, at the same time, RLAE and SLA decreased (Table 2). 


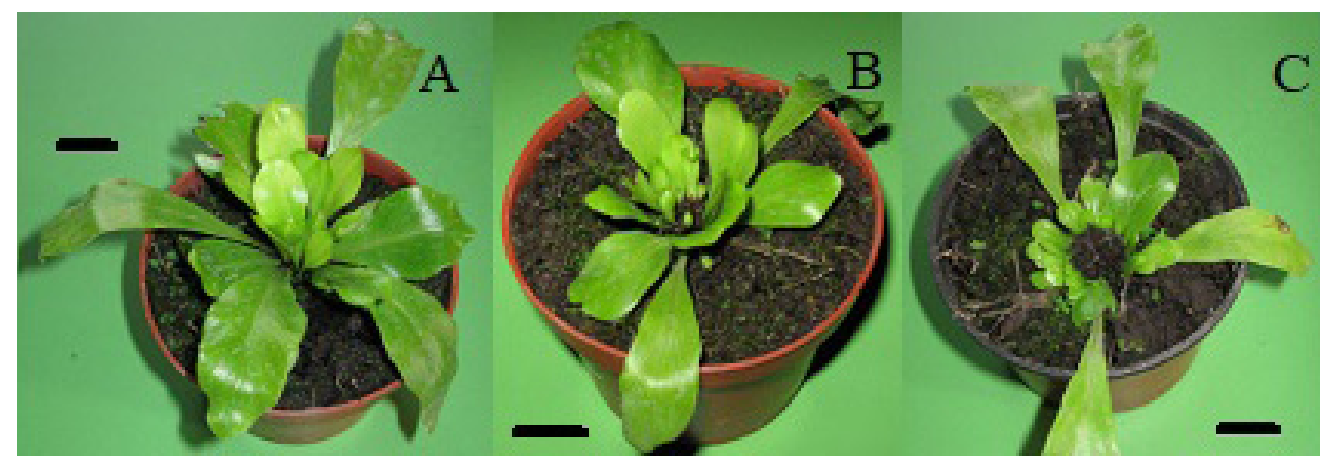

Figure 4. Asplenium nidus plants sprayed with $5 \mathrm{mg} \mathrm{L}^{-1}$ 6-benzyl aminopurine (BAP) one (7 days after transplant) (A), two (7 and 30 days after transplant) (B) and three times (7, 30, and 60 days after transplant) (C) at the end of Experiment 2. Lines indicate the $1 \mathrm{~cm}$ scale.

Table 2. Effects of five 6-benzyl aminopurine (BAP) concentrations (0, 5, 50, 100 or $\left.200 \mathrm{mg} \mathrm{L}^{-1}\right)$ applied once (7 days after transplant) (I), twice ( 7 and 30 days after transplant) II or three times (7, 30, and 60 days after transplant) (III) on frond number, total frond area and specific leaf area (SLA) on a fresh weight base at the end of Experiment 2, rate of leaf appearance (RLA) and relative leaf expansion rate (RLAE) in Asplenium nidus plants. Different lower case letters indicate significant differences $(p<0.05)$ between treatments according the Tukey's Test (number of frond and frond area) or SMATR analysis (RLA, RLAE and SLA).

\begin{tabular}{|c|c|c|c|c|c|}
\hline $\begin{array}{c}\text { BAP } \\
\left(\mathrm{mg} \mathrm{L}^{-1}\right)\end{array}$ & $\begin{array}{c}\text { Number of fronds } \\
\text { plant }^{-1}\end{array}$ & $\begin{array}{c}\text { RLA } \\
\text { (fronds week-1) }\end{array}$ & $\begin{array}{l}\text { Frond area } \\
\left(\mathrm{cm}^{2} \text { frond }^{-1}\right)\end{array}$ & $\begin{array}{c}\text { RLAE } \\
\left(\mathrm{cm}^{2} \mathbf{c m}^{-2} \mathrm{day}^{-1}\right)\end{array}$ & $\begin{array}{c}\text { SLA } \\
\left(\mathrm{cm}^{2} \mathbf{g}^{-1}\right)\end{array}$ \\
\hline 0 & $16.8 \mathrm{~d}$ & $0.556 f$ & $106.28 \mathrm{a}$ & $0.0133 a$ & $23.74 \mathrm{a}$ \\
\hline I-5 & $22.3 d$ & $0.622 f$ & $84.98 b$ & $0.0118 b$ & $22.71 b$ \\
\hline $\mathrm{I}-50$ & $30.1 \mathrm{c}$ & $0.861 \mathrm{e}$ & $66.38 \mathrm{c}$ & $0.0099 \mathrm{c}$ & $22.13 b$ \\
\hline I- 100 & $33.7 \mathrm{~b}$ & $0.861 \mathrm{e}$ & $67.06 \mathrm{c}$ & $0.0092 \mathrm{c}$ & $21.14 b$ \\
\hline I-200 & $35.1 \mathrm{~b}$ & $1.083 \mathrm{~d}$ & $71.45 \mathrm{c}$ & $0.0098 \mathrm{c}$ & $19.84 b$ \\
\hline II-5 & $23.5 \mathrm{~d}$ & $0.761 \mathrm{e}$ & $72.64 c$ & $0.0126 b$ & $22.83 b$ \\
\hline II-50 & $30.4 c$ & $0.967 d$ & $71.90 \mathrm{c}$ & $0.0093 \mathrm{c}$ & $22.03 b$ \\
\hline II- 100 & $34.7 b$ & $1.067 \mathrm{~d}$ & $48.91 d$ & $0.0094 \mathrm{c}$ & $21.66 \mathrm{~b}$ \\
\hline II-200 & $36.6 b$ & $1.222 \mathrm{~b}$ & $54.10 \mathrm{~d}$ & $0.0091 \mathrm{c}$ & $21.15 b$ \\
\hline III-5 & $24.1 d$ & $0.811 \mathrm{e}$ & $66.49 \mathrm{c}$ & $0.0102 c$ & $22.16 b$ \\
\hline III-50 & $31.6 \mathrm{c}$ & $1.044 \mathrm{~d}$ & $50.72 d$ & $0.0098 \mathrm{c}$ & $21.83 b$ \\
\hline III-100 & $35.2 \mathrm{~b}$ & $1.122 \mathrm{c}$ & $44.97 d$ & $0.0101 \mathrm{c}$ & $21.18 b$ \\
\hline III-200 & $38.9 \mathrm{a}$ & $1.306 \mathrm{a}$ & $41.47 \mathrm{e}$ & $0.0094 \mathrm{c}$ & $18.94 \mathrm{c}$ \\
\hline
\end{tabular}

The fern A. nidus has an apical cell-based meristem with a distinct single apical initial cell, which is always formed during, and is responsible for, the early development of the gametophyte (Bartz and Gola, 2018). However, the unusual increase in the shoot apical meristem shown in Figures 1 and 4 was the result of both biomass stem accumulation and lateral meristem differentiation (Figure 2). In this regards, Romanenko et al. (2019) showed that during in vitro propagation of the fern Dryopteris filixmas, cytokinin inhibits gametophyte development, reduces the size, or causes multiple overgrowth and deformation of the heart-shaped thallus, and affects the formation of gametes. Although a common BAP-spray response is a change in photo assimilate partitioning which favor stems (Di Benedetto et al., 2020a), there are no previous reports of that extreme response in fern sporophytes or other ornamental plants grown at commercial pot growing.

The main changes observed in plant attributes during Experiments 1 and 2 were related to an increase in the number of fronds per plant and a decrease in total frond area (Table 1 and Figure 3 ). These results may be explained by RLA (as an estimator of frond initiation) and RLAE (as an estimator of frond expansion). On the other hand, SLA (as an estimator of frond thickness) decreased as well, involving an increase in frond thickness (Tables 1 and 2). As a result, the higher number of new fronds initiated were small and thick.

Fern fronds are considered to be structures with delayed determinacy, with a frond apical meristem similar to the SAM in vascular plants. In ferns, the SAM is responsible 
for a transient indeterminacy during frond development, usually producing lateral pinnae during a longer period (Cruz et al., 2020). In this regards, class I KNOX genes are known to be expressed in the SAM and frond primordia, as well as in the pinnae of compound fern leaves, suggesting that the same network for compound leaf development might be in place in ferns and seed plants (Vasco and Ambrose, 2020). Since cytokinin has been involved in Class I KNOX gene regulation (Rashotte, 2020), we can hypothesize that an exogenous BAP spray to $A$. nidus plants over-increases cytokinin levels at the SAM and leads to a negative growth signal (Figures 1 and 4).

At the end of Experiment 1, total DW decreased $(43.00 \%)$ as BAP concentration increased. Figure 5A shows that, although all plant organs decreased biomass accumulation on a DW basis, fronds were the ones mainly affected. On the other hand, data from Experiment 2 showed that total DW decreased in response to an increase in BAP concentration, which was amplified with consecutive BAP applications (Figure 5B).
A

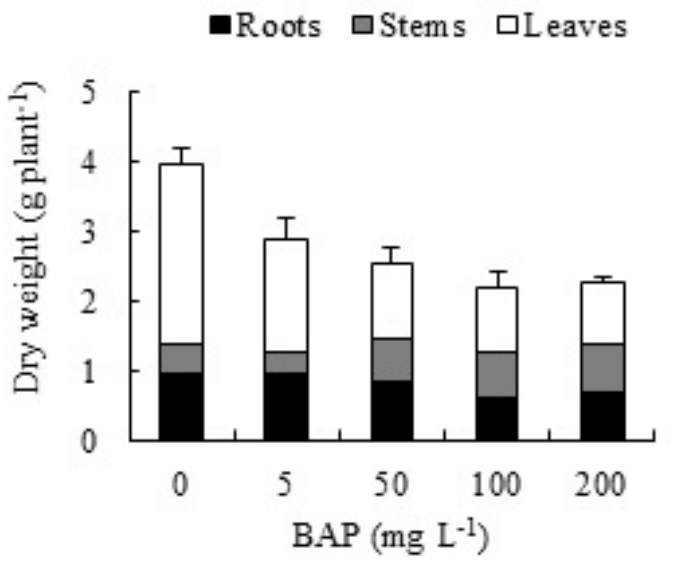

B

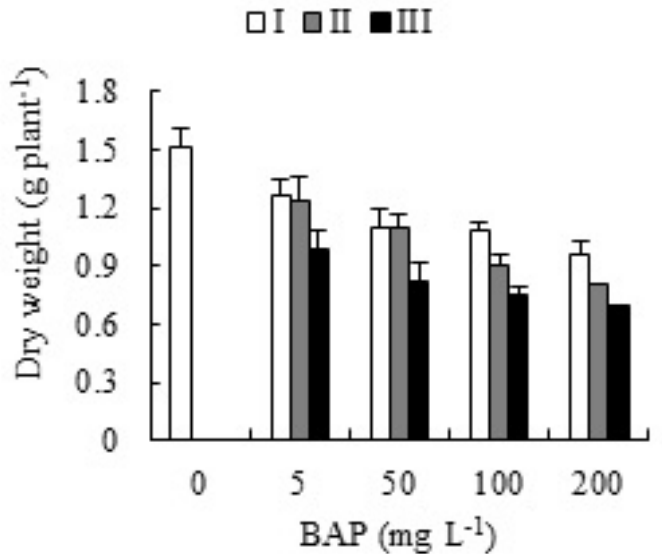

Figure 5. Effects of five 6-benzyl aminopurine (BAP) concentrations on dry weight partitioned between different plant organs at the end of the experiment 1 (A) and total dry weight at the end of experiment 2 when five BAP concentrations were applied once ( 7 days after transplant) (I), twice ( 7 and 30 days after transplant) II or three times (7, 30, and 60 days after transplant) (III) in Asplenium nidus plants. Bars indicate standard errors.

Table 3 shows a decrease in RGR (70.19\%) and NAR $(23.03 \%)$, which explains the decrease in total DW in response to higher single BAP concentrations. A decrease in LAP and the $\beta$ coefficient from root: shoot allometries explained the higher biomass accumulation in shoots, while the changes in the $\beta$ coefficient from fronds: stems allometries explained the sudden increase in the SAM observed in Figures 1, 2 and 4.

Table 3. Effects of five 6-benzyl aminopurine (BAP) concentrations $\left(0,5,50,100\right.$ or $\left.200 \mathrm{mg} \mathrm{L}^{-1}\right)$ on the relative growth rate (RGR), net assimilation rate (NAR), leaf area ratio (LAR), leaf area partitioning (LAP) and $\beta$ coefficients from roots: shoots and fronds: stems allometries during Experiment 1 in Asplenium nidus plants. Different lower case letters indicate significant differences $(p<0.05)$ between treatments according the Tukey's Test (number of frond and frond area) or SMATR analysis (RGR and NAR).

\begin{tabular}{|c|c|c|c|c|c|c|}
\hline $\begin{array}{c}\text { BAP } \\
\left(\mathrm{mg} \mathrm{L}^{-1}\right)\end{array}$ & $\begin{array}{c}\text { RGR } \\
\left(\mathrm{g} \mathrm{g}^{-1} \text { day }^{-1}\right)\end{array}$ & $\begin{array}{c}\text { NAR } \\
\left(\mathrm{g} \mathrm{cm}^{-2} \mathrm{day}^{-1}\right) \times 10^{-5}\end{array}$ & $\begin{array}{c}\text { LAR } \\
\left(\mathrm{cm}^{2} \mathbf{g}^{-1}\right)\end{array}$ & $\begin{array}{c}\text { LAP } \\
\mathrm{cm}^{2} \mathrm{day}^{-1} / \mathrm{g} \mathrm{day}^{-1}\end{array}$ & $\begin{array}{c}\text { Root: shoot } \\
\beta\end{array}$ & $\begin{array}{c}\text { Fronds: stems } \\
\beta\end{array}$ \\
\hline 0 & $0.0104 a$ & $12.59 \mathrm{a}$ & $82.61 \mathrm{a}$ & $78.64 a$ & $1.98 \mathrm{a}$ & $1.80 \mathrm{a}$ \\
\hline 5 & $0.0080 \mathrm{~b}$ & $11.27 \mathrm{~b}$ & $70.96 b$ & $66.52 b$ & $1.70 \mathrm{~b}$ & $1.39 \mathrm{~b}$ \\
\hline 50 & $0.0078 b$ & $11.98 \mathrm{~b}$ & $64.36 c$ & $53.63 \mathrm{c}$ & $0.99 \mathrm{c}$ & $0.57 \mathrm{c}$ \\
\hline 100 & $0.0081 \mathrm{~b}$ & $10.59 b$ & $64.32 c$ & $54.00 \mathrm{c}$ & $0.97 \mathrm{c}$ & $0.40 \mathrm{~d}$ \\
\hline 200 & $0.0031 \mathrm{c}$ & $9.69 \mathrm{c}$ & $31.98 \mathrm{~d}$ & $-2.06 \mathrm{~d}$ & $0.50 \mathrm{~d}$ & $0.06 \mathrm{e}$ \\
\hline
\end{tabular}


During Experiment 2, RGR and NAR decreased with the BAP concentration and the number of applications (Table 4). On the other hand, in agreement with Experiment 1, LAP and $\beta$ coefficients from the roots: shoots and fronds: stems allometries showed higher photo-assimilate partitioning to shoots and stems respectively with the use of BAP in single or repeated applications (Table 4).

Table 4. Effects of five 6-benzyl aminopurine (BAP) concentrations (0, 5, 50, 100 or $\left.200 \mathrm{mg} \mathrm{L}^{-1}\right)$ applied once (7 days after transplant) (I), twice (7 and 30 days after transplant) II or three times (7, 30, and 60 days after transplant) (III)on the relative growth rate (RGR), net assimilation rate (NAR), leaf area ratio (LAR), leaf area partitioning (LAP) and $\beta$ coefficient from the roots: shoots and leaves: stems allometries in Asplenium nidus plants. Different lower case letters indicate significant differences $(p<0.05)$ between treatments according the Tukey's Test (number of frond and frond area) or SMATR analysis (RGR and NAR).

\begin{tabular}{|c|c|c|c|c|c|c|}
\hline 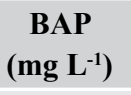 & $\begin{array}{c}\text { RGR } \\
\left(\mathrm{g} \mathrm{g}^{-1} \text { day }^{-1}\right)\end{array}$ & $\begin{array}{c}\text { NAR } \\
\left(\mathrm{g} \mathrm{cm}^{-2} \text { day }^{-1}\right) \times 10^{-5}\end{array}$ & $\begin{array}{c}\text { LAR } \\
\left(\mathrm{cm}^{2} \mathbf{g}^{-1}\right)\end{array}$ & $\begin{array}{c}\text { LAP } \\
\left(\mathrm{cm}^{2} \mathrm{day}^{-1} / \mathrm{g} \mathrm{day}^{-1}\right)\end{array}$ & $\begin{array}{c}\text { Shoot: root } \\
\beta\end{array}$ & $\begin{array}{c}\text { Leaves: stem } \\
\beta\end{array}$ \\
\hline 0 & $0.0182 \mathrm{a}$ & $24.22 \mathrm{a}$ & $75.14 b$ & $77,86 \mathrm{a}$ & $1.12 \mathrm{a}$ & $3.01 \mathrm{a}$ \\
\hline $\mathrm{I}-5$ & $0.0150 \mathrm{~b}$ & $17.93 b$ & $83.66 \mathrm{a}$ & $68,90 \mathrm{~b}$ & $0.80 \mathrm{~b}$ & $1.46 \mathrm{~b}$ \\
\hline I-50 & $0.0148 b$ & $19.69 \mathrm{~b}$ & $75.17 b$ & $68,05 b$ & $0.86 \mathrm{~b}$ & $1.14 \mathrm{~d}$ \\
\hline $\mathrm{I}-100$ & $0.0129 \mathrm{c}$ & $15.92 \mathrm{c}$ & $81.03 \mathrm{a}$ & $67,31 \mathrm{~b}$ & $0.69 \mathrm{c}$ & $0.65 \mathrm{e}$ \\
\hline $\mathrm{I}-200$ & $0.0130 \mathrm{c}$ & $15.54 \mathrm{c}$ & $83.66 \mathrm{a}$ & $66,57 b$ & $0.43 \mathrm{~d}$ & $0.50 \mathrm{f}$ \\
\hline II-5 & $0.0146 b$ & $16.18 \mathrm{c}$ & $90.23 a$ & $65,80 \mathrm{~b}$ & $0.62 b$ & $1.29 \mathrm{~g}$ \\
\hline II-50 & $0.0118 \mathrm{c}$ & $13.50 \mathrm{~d}$ & $87.41 \mathrm{a}$ & $63,52 b$ & $0.57 \mathrm{~b}$ & $1.11 \mathrm{~d}$ \\
\hline II-100 & $0.0133 \mathrm{c}$ & $16.62 \mathrm{c}$ & $80.02 \mathrm{a}$ & $63,06 \mathrm{~b}$ & $0.34 \mathrm{c}$ & $0.63 \mathrm{e}$ \\
\hline II-200 & $0.0118 \mathrm{c}$ & $13.67 \mathrm{~d}$ & $86.32 \mathrm{a}$ & $59,65 \mathrm{~b}$ & $0.26 \mathrm{c}$ & $0.34 \mathrm{c}$ \\
\hline III-5 & $0.0130 \mathrm{c}$ & $15.16 \mathrm{c}$ & $85.75 a$ & $57,81 \mathrm{c}$ & $0.61 \mathrm{~b}$ & $1.19 \mathrm{~d}$ \\
\hline III-50 & $0.0134 c$ & $16.43 \mathrm{c}$ & $81.56 \mathrm{a}$ & $56,57 \mathrm{c}$ & $0.43 \mathrm{c}$ & $0.71 \mathrm{e}$ \\
\hline III-100 & $0.0133 \mathrm{c}$ & $15.90 \mathrm{c}$ & $83.65 \mathrm{a}$ & $54,92 \mathrm{c}$ & $0.29 \mathrm{~d}$ & $0.62 \mathrm{e}$ \\
\hline III-200 & $0.0120 \mathrm{c}$ & $13.81 \mathrm{~d}$ & $86.89 a$ & $50,27 \mathrm{c}$ & $0.22 \mathrm{~d}$ & $0.29 \mathrm{~g}$ \\
\hline
\end{tabular}

According to Page (2002), the main important disadvantages of the biology of ferns are the low-light photosynthetic capacity and the slow plant growth rates. Although differences in control plants were found between experiments (likely related to different spore-propagated $A$. nidus batches), RGR values were higher than those of other related fern species (Liao et al., 2017), with a significant decrease in BAP-sprayed plants (Tables 3 and 4). NAR values changed in the same way as RGR and would explain the results on DW accumulation shown in Figure 5. On the other hand, the distribution of biomass among plant organs is affected by the environment, habit of the plant, life span of the plant, and competitive interactions, and the growth rate is always controlled by the source-sink balance within the plant. This can be illustrated by the LAP growth parameter and both the roots: shoots and fronds: stems allometries, which, in our experiments, favored photoassimilate partitioning to the SAM (Tables 3 and 4) when a single or repeated BAP spray was applied. As a result, RLA clearly increased and a significantly high number of fronds developed, but could not be sustained by the limited photosynthetic rate at this growth stage. Regarding this issue, Martin et al. (2004) examined numerous physiological parameters in individuals of varying sizes of A. nidus and found that the rates of net $\mathrm{CO}_{2}$ exchange of the fronds measured in situ in the field appeared to increase with plant size.

Babenko et al. (2018) indicated that high BAP concentrations inhibited spore germination and gametophyte development of Polystichum aculeatum, whereas lower quantities showed slight stimulating effect, which clearly indicates that cytokinin can undoubtedly regulate the growth and development of ferns. On the other hand, Vedenicheva and Kosakivska (2017) indicated that the accumulation of trans-zeatin in fronds of $P$. aculeatum and Dryopteris filix-mas was revealed at the intensive growth stage, and that the level of zeatin riboside increased in fronds and rhizomes of both fern species at the stage of sporulation. These authors also found that the root system of both fern species was characterized by a lower level of cytokinin as compared to the aerial part.

\section{Conclusions}

The unusual results in Asplenium nidus when younger sporophytes were sprayed with different BAP doses (Experiment 1) at single or repeated times (Experiment 2) would be explained by a lower endogenous cytokinin level in control plants (such as that found in other ferns) and an excessive cytokinin increase from exogenous 
BAP applications, which significantly increased photoassimilate partitioning to the SAM. This led to an excessive decrease in the frond plastochron and a significantly higher frond number initiated at the SAM. The expansion of these excessive new fronds could not be sustained due to the low net photosynthetic rate of the previously expanded fronds, which limited the outward plant appearance and the sale opportunity.

\section{Author Contribution}

AP, JM: provided the structure and conditions to develop the experiments and conducted its. ADB, DC, EG: wrote the manuscript, carried out the statistical analysis and contributed to the discussion of results. All the authors read and approved the final version of the paper.

\section{Acknowledgements}

This work was supported by the University of Buenos Aires Science Program 2017-2020 (Grant No 145BA).

\section{References}

BABENKO, L.M.; ROMANENKO, K.O.; SHCHERBATIUK, M.M.; VASHEKA, O.V.; ROMANENKO, P.O.; NEGRETSKY, V.A.; KOSAKIVSKA, I.V. Effects of exogenous phytohormones on spore germination and morphogenesis of Polystichum aculeatum (L.) Roth gametophyte in vitro culture. Cytology and Genetics, v.52, n.2, p.117-126, 2018. https://doi. org/10.3103/ S0095452718020032

BARTZ, M.; GOLA, E.M. Meristem development and activity in gametophytes of the model fern, Ceratopteris richardii. Developmental Biology, v.444, n.2, p.107-115, 2018. https://doi.org/10.1016/j.ydbio.2018.10.005

CRUZ, R.; MELO-DE-PINNA, G.F.; VASCO, A.; PRADO, J.; AMBROSE, B.A. Class I KNOX is related to determinacy during the leaf development of the Fern Mickelia scandens (Dryopteridaceae). International Journal of Molecular Sciences, v.21, n.12, p.4295, 2020. https://doi.org/10.3390/ijms21124295

DI BENEDETTO, A.; TOGNETTI, J. Técnicas de análisis de crecimiento de plantas: su aplicación a cultivos intensivos. RIA, v.42, p.258-282, 2016.

DI BENEDETTO, A.; GIARDINA, E.; DE LOJO, J.; GANDOLFO, E.; HAKIM, G. Exogenous benzyl aminopurine (BAP) applications for the ornamental pot industry. In: KORTESMÄKI, S. Cytokinins: Biosynthesis and Uses. New York: Nova Science Publishers, 2020a. p.1-56.
DI BENEDETTO, A.; RATTIN, J.; CARNELOS, D.; LOZANO-MIGLIOLI, J.; GIARDINA, E.; ARAKI, A.; CORO, M.; PICO-ESTRADA, O.; TERUEL, J.; DI MATTEO, J.; GERASI, J.; BARRERA, L.; ALONSO, E.; GRIGOLI, L. Technological uses of exogenous cytokinins in vegetables. In: KORTESMÄKI, S. Cytokinins: Biosynthesis and Uses. New York: Nova Science Publishers, 2020b. p.107-155.

FERNANDEZ, H.; BERTRAND, A.; SANCHEZTAMES, R. In vitro regeneration of Asplenium nidus L. from gametophytic and sporophytic tissue. Scientia Horticulturae, v.56, n.1, p.71-77, 1993. https://doi. org/10.1016/0304-4238(93)90103-W

KOSAKIVSKA, I.V.; BABENKO, L.M.; SHCHERBATIUK, M.M.; VEDENICHEVA, N.P.; VOYTENKO, L.V.; VASYUK, V.A. Phytohormones during growth and development of Polypodiophyta. Advances in Biology \& Earth Sciences, v.1, n.1, p.26-44, 2016.

LIAO, J.X.; ZHANG, H.; MO, L.; HUANG, Y.Q.; SUN, Y.J.; LI, Y.Q. Differences in growth and biomass allocation of Adiantum flabellulatum and A. capillus-veneris as a result of light and water availability. Botany Letters, v.164, n.4, p.393-400, 2017. https://doi.org/10.1080/2381 8107.2017.1396496

MARTIN, C.E.; LIN, T.C.; HSU, C.C.; LIN, S.H.; LIN, K.C.; HSIA, Y.J.; CHIOU, W.L. Ecophysiology and plant size in a tropical epiphytic fern, Asplenium nidus, in Taiwan. International Journal of Plant Science, v.165, p.65-72, 2004. https://doi.org/10.1086/380982

MENÉNDEZ, V.; ARBESÚ, R.; SOMER, M.; REVILLA, A.; FERNÁNDEZ, H. From spore to sporophyte: How to proceed in vitro. In: FERNÁNDEZ, H.; KUMAR, A.; REVILLA, A. Working with Ferns: Issues and Applications. Berlin/Heidelberg, Springer, 2010. 410p.

PAGANI, A.; MOLINARI, J.; GIARDINA, E.; DI BENEDETTO, A. Biomass accumulation in the fern Asplenium nidus avis under root restriction. Asian Journal of Agricultural and Horticultural Research, v.6, p.1-9. 2020. https://doi.org/10.9734/AJAHR/2020/v6i430077

PAGE, C.N. Ecological strategies in fern evolution: a neopteridological overview. Review of Palaeobotany and Palynology, v.119, n.1-2, p.1-33, 2002. https://doi. org/10.1016/S0034-6667(01)00127-0

RASHOTTE, A.M. The evolution of cytokinin signaling and its role in development before Angiosperms. Seminars in Cell \& Developmental Biology. 2020 (in press). https:// doi.org/10.1016/j.semcdb.2020.06.010 
RAVI, B.X.; VARUVEL, G.V.A.; ROBERT, J. Apogamous sporophyte development through spore reproduction of a South Asia's critically endangered fern: Pteris tripartita Sw. Asian Pacific Journal of Reproduction, v.4, n.2, p.135139, 2015. https://doi.org/10.1016/S2305-0500(15)30010-5

ROMANENKO, K.O.; KOSAKIVSKA, I.V.; BABENKO, L.M.; VASHEKA, O.V.; ROMANENKO, P.O.; NEGRETSKY, V.A.; MINARCHENKO, V.M. Effects of Exogenous cytokinins on spore germination and gametophyte morphogenesis of Dryopteris filix-mas (L.) Schott in vitro culture. Cytology and Genetics, v.53, n.3, p.192-201, 2019. https://doi.org/10.3103/ S0095452719030034

SOUHEIL, H.; ROLA, B. In vitro propagation of ferns (Asplenium nidus) via spores culture. Jordan Journal of Agricultural Science, v.10, n.1, p. 144-153, 2014.
VASCO, A.; AMBROSE, B.A. Simple and divided leaves in ferns: exploring the genetic basis for leaf morphology differences in the genus Elaphoglossum (Dryopteridaceae). International Journal of Molecular Sciences, v.21, n.15, p.5180, 2020. https://doi.org/10.3390/ijms21155180

VEDENICHEVA, N.P.; KOSAKIVSKA, I.V. Endogenous cytokinins dynamics during development of sporophytes of perennial ferns Dryopteris filix-mas and Polystichum aculeatum (Dryopteridaceae). Ukrainian Botanical Journal, v.75, n.4, p.384-391, 2018. https://doi. org/10.15407/ukrbotj75.04.384 